\title{
Forage allocation: Science or politics?
}

\section{Both must be considered in managing for common use in the East Kootenay, British Columbia.}

\author{
By Brian M. Wikeem and Timothy J. Ross
}

attle, mule deer, whitetail deer, and elk have shared grassland and open forest range in the Rocky Mountain Trench of southeastern British Columbia (BC) (Fig. 1) for more than a century, and conflicts about overlapping ungulate populations and

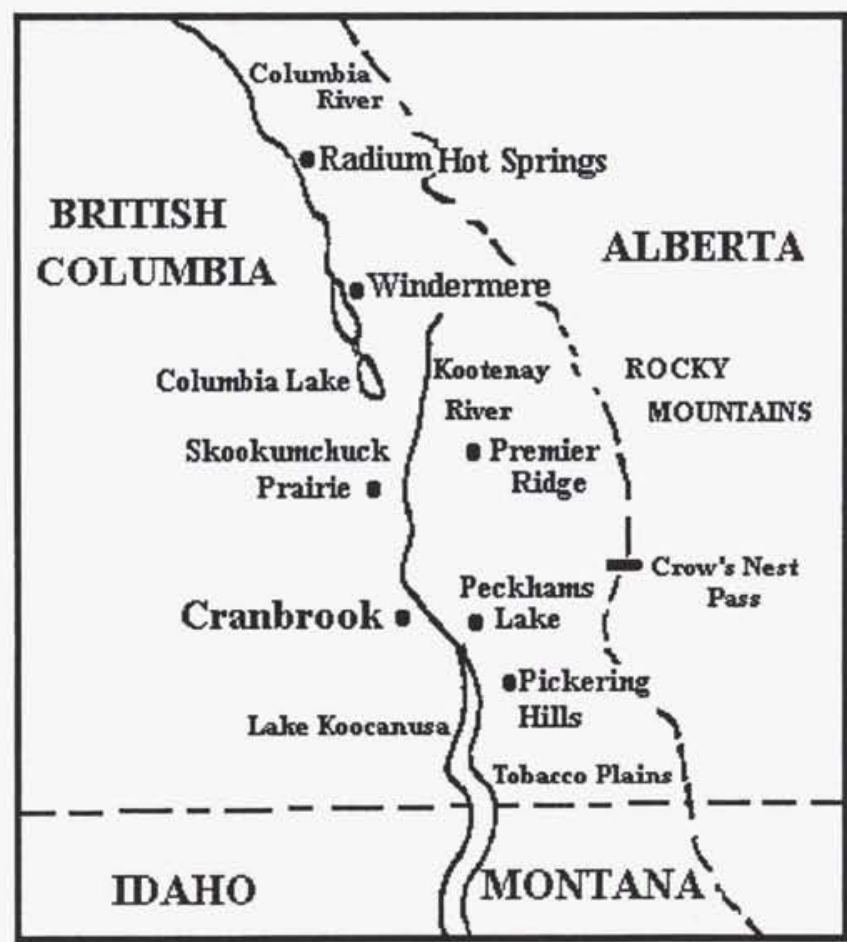

Fig. 1. Rocky Mountain Trench from Radium Hot Springs to the Tobacco Plains in southeastern British Columbia.

presumed competition have persisted for over 40 years.

While the direct impacts of large ungulates dominate the debate, other factors such as historical grazing and fires, fire suppression, forest encroachment, logging, land alienation, and recreation all have contributed to declining range and wildlife habitat resources in the area.

It was finally recognized that an equitable forage allo- cation process is necessary to mitigate conflicts Although inventory and monitoring can tell us how much forage is available, they cannot tell us what is ecologically sustainable and equitable among users.

\section{A Historical Look}

Information on pre-European grazing in the Trench is largely anecdotal. Although it is widely contended that large populations of wild ungulates were not present in the inter-mountain regions of the Pacific Northwest, bones collected from two archaeological sites dating from 8000 B.C. to 100 suggest that bison historically occupied the Trench. Other sources suggest that bison may have been extirpated early in the $19^{t / 1}$ century.

Historically, ungulate populations have been variable in the East Kootenay. Both David Thompson and the Palliser Expedition reported that elk and deer were scarce in the early- and mid-1800s and they complained of food shortages to the point of near starvation.Additionally, the Kootenay Indians, who are indigenous to the Trench, travelled to Alberta for buffalo meat during the $1700 \mathrm{~s}$ and 1800 s because game was scarce.

Elk may have been traditionally abundant but severe winters significantly reduced populations throughout BC in the mid-and late-1800s. Apparently, no elk were west of the Kootenay River until the late-1940s, even though populations of both deer and elk increased dramatically during the $1940 \mathrm{~s}$ and $1950 \mathrm{~s}$.

Horses were another historical factor on East Kootenay rangelands.As early as 1792 , explorer Peter Fidler met Kootenay Indians in the Alberta foothills who were trading horses with the Peigan Indians of the Great Plains. Later, David Thompson reported trading the Kootenay for horses in the Trench from 1807 to 1811. By the $1880 \mathrm{~s}$, the natives around Joseph's Prairie (present day Cranbrook) had about 2,000 horses and another 5,000 horses were reported grazing at Tobacco Plains, south of Cranbrook, about the same time (Fig. 1).

The first cattle in the Trench came from Fort Garry (Winnipeg) in 1841 and 1854 but early settlement did not 
begin until the $1880 \mathrm{~s}$. During this period, most ranches ran 50-125 cattle, but several ranchers had herds ranging from 200 to 300 head. By 1900, James McKay, who ranched near Windermere, $\mathrm{BC}$, had over 1,000 cattle.

Other disturbances such as logging, mining, hydro development, and recreation also contributed to the present composition of plant communities in recent history, but fire has been a major factor. The Kootenay Indians used fire to create open range for their horses before European settlement.

More recently, numerous large fires were started between 1914 and 1931 in association with early logging and construction of the Canadian Pacific railroad, which created large areas of habitat and abundant fordge for livestock and wildlife.

Fire-suppression began in the Trench in the 1920s and, subsequently, forests have become overstocked and stagnant instead of regulating themselves by "self-thinning". Consequently, forest ingrowth and encroachment have resulted in a significant reduction of open range for wildlife and livestock grazing.

\section{Current Wildlife \& Cattle Numbers}

The elk population increased from about 10,000 to more than 28,000 between 1982 and 1986, and currently the population is nearly 20,000 . Wildlife managers concluded in a recent elk management plan that: "Current habitat condition on all potential winter range (gross suitability) is estimated to support 41,400 elk, while the net suitability (minus private land) has the potential to support 24,400 elk".

By contrast, livestock Animal Unit Months (AUMs) in the Trench peaked in 1964 (72,900 AUMs) but by 1980 , they were down to 41,200 AUMs, and have remained relatively constant since.

A series of wildlife, soil, and range surveys between 1953 and 1956 concluded that grasslands in the Trench were overgrazed and the carrying capacity for wildlife and livestock was below its capability. Specifically, the following problems and concerns were identified:

- Livestock were being turned-out before range readiness.

- Ranges were overstocked with livestock.

- Bunchgrasses were being overused.

- Bluebunch wheatgrass and rough fescue were becoming scarce on the open range compared to areas protected from grazing.

- Livestock were reluctant to graze forest range and areas remote from water.

- Overuse was particularly high near water.

- Weeds were invading grassland range.

Dr. Michael Pitt from the University of British Columbia reviewed the problems associated with common use of rangelands by wildlife and cattle in the East
Kootenay in 1982. He found that most resource managers agreed that combined grazing pressure, forest ingrowth, and land alienation were resulting in declining range condition in parts of the Trench.

Conversely, there was considerable disagreement regarding who was responsible for these trends. Wildlife supporters contended that high cattle stocking rates, and improper seasons of use were responsible for the deterioration in range condition and forage production potential on critical wildlife winter ranges. In contrast, ranching advocates argued that overgrazing resulted from increased wildlife populations using low-elevation rangelands when cattle were not present.

The East Kootenay Trench Agriculture/Wildlife Committee was established in 1990 to address resource management conflicts in the Trench. The Committee's principal objective was to recommend an equitable forage allocation process that protects Crown range resources while recognizing the interests of both the livestock and wildlife industries. A monitoring program was established to provide local biological information to assist in the process.

\section{What Did Monitoring Tell Us?}

Monitoring was conducted at four locations in the Trench within $60 \mathrm{~km}$ of Cranbrook, BC (Figure 1). Each site is an important winter range for deer and elk, and rotationally grazed by cattle. All four locations also represent significant areas of conflict in the Trench.

Skookumchuck Prairie is predominantly open grassland interspersed with groves of ponderosa pine and trembling aspen. Herbaceous vegetation consists of Kentucky bluegrass, Canada bluegrass, Richardson's needlegrass, rough fescue, Idaho fescue, bluebunch wheatgrass, and a variety of forbs, while bitterbrush and Saskatoon were important browse species on the site.

Vegetation at Premier Ridge and Pickering Hills consists of open grass/shrub land interspersed with groves of Douglas-fir mixed with ponderosa pine and trembling aspen. Both sites are in a low seral stage dominated by Kentucky bluegrass and western needlegrass although rough fescue and bluebunch wheatgrass can be found very infrequently. Again, bitterbrush and Saskatoon were the dominant shrubs on both sites.

Two sites are located at Peckhams Lake on pastures seeded to domestic forages and interspersed with Douglas-fir forest. Although some native species are present, orchardgrass, smooth bromegrass, slender wheatgrass, alfalfa, and alsike clover dominate both sites while shrubs are generally absent.

The climate in the Trench is semi-arid with weather patterns influenced by cold continental air masses from the north in winter, and from heated air masses from the southern interior plateau of the United States (US) in summer. Normal mean annual precipitation is $366 \mathrm{~mm}$. 
All four sites were monitored from 1990 to 1993 to address the following components of the forage allocation process:

- Total and seasonal forage standing crop during spring, summer, fall and winter grazing periods.

- Seasonal and annual diets of cattle, deer and elk.

- Seasonal and annual forage use.

- Range condition and trend.

1) Forage Standing Crop - Seasonal and total standing crops were measured to determine the amount of herbaceous matter produced during different grazing periods, and over the entire growing season. Total precipitation equalled 98,133 and $90 \%$ of normal in 1992 , 1993 , and 1994, respectively. Both seasonal and total standing crop varied at all sites in response to annual

Table 1. Total standing crop ( $\mathrm{kg} / \mathrm{ha}$ ) among five sites in the East Kootenay between 1992 and 1994.

\begin{tabular}{|c|c|c|c|}
\hline Site & 1992 & 1993 & 1994 \\
\hline & & $(\mathrm{kg} / \mathrm{ha})$ & \\
\hline Skookumchuck Prairiel & 715 & 925 & 900 \\
\hline Premier Ridge & 830 & 1170 & 865 \\
\hline Pickering Hills & 840 & 1110 & 1135 \\
\hline Peckhams Lake (New Seeding) & 2370 & 3005 & 1115 \\
\hline Peckhams Lake (Old Seeding) & 2280 & 4250 & 1760 \\
\hline Average & 1405 & 2090 & 930 \\
\hline
\end{tabular}

Data rounded to nearest $5 \mathrm{~kg} / \mathrm{ha}$.

precipitation patterns (Table 1).

Averaged over all sites, total forage standing crop was $81 \%$ higher in the wettest year (1993) compared to the driest (1994). Similarly, average total standing crop ranged from 11 to $43 \%$ higher than seasonal standing crop among years but there were considerable differences among sites (Table 1).

Allocation procedures need to account for seasonal and annual variations in forage production, and carrying capacity must be based on the combined stocking rates of livestock and wildlife. Both cattle stocking rates, and wildlife population levels, must be set and maintained to ensure the sustainability of the range resource under common use.

Where forage is limiting on native spring ranges, the impacts of combined wildlife and cattle use can be mitigated by developing seeded spring pastures for livestock. Similarly, seeded pastures have been successful in other jurisdictions as "intercept ranges" to provide forage for wildlife before they occupy the winter range.

2) Ungulate Diets - Seasonal diets of deer, elk and cattle were monitored on all four sites to establish the degree of diet overlap. Results from the monitoring were generally consistent among the sites studied, and with previous research on deer, elk and cattle in $\mathrm{BC}$,
Alberta and the western US using similar habitat.

Deer and elk ate 31 to 63 species over the three years and 18 to 25 species annually. Cattle diets were less diverse and comprised only $70 \%$ of the species eaten by deer and elk. About 12 key species, however, dominated diets of all three ungulates.

Shrubs and trees dominated deer diets in all years (range 24 to $98 \%$ ) with bitterbrush and buckbrush being the most important species in winter. Grasses were generally unimportant in deer diet $(<10 \%)$ except in spring when they comprised nearly $20 \%$ of the diet. Alfalfa and clover were used infrequently $(<5 \%)$ in all years.

Elk mainly ate grasses, especially in winter and spring. Rough fescue, Idaho fescue, and bluegrasses were the dominant species eaten but elk also grazed alfalfa and clover in summer and fall. Trees and shrubs averaged up to $35 \%$ of elk winter diet with soopolallie, low Oregongrape, and Douglas-fir the most important species browsed.

Grasses and forbs dominated cattle diets while shrubs generally were eaten sparingly. Rough fescue, Idaho fescue, and bluegrasses were the most important grasses in their diet while shrubs and forbs were eaten most in spring, summer and fall.

Competition for forage could be a factor on some, or all of the pastures monitored in this study given seasonal and annual diet similarities between cattle and elk. Indeed, cattle likely compete with elk in fall and winter through their summer grazing in some years. Similarly, elk can compete with cattle on summer range through spring grazing on sympatric habitats. Although cattle and elk diets were similar, competition is expected only if food or space is limited. No competition is expected by elk with deer, or by cattle with deer, except possibly for specific species such as bitterbrush in particular years.

3) Total Forage Use - A proper-use factor of 50\% utilization is commonly recommended on many range types in North America. Combined use by wildlife and cattle ranged from about $50 \%$ to $>90 \%$ of the total standing crop during the study but total use often exceeded $70 \%$. Forage use on native range was equally split between wildlife (17 and 30\% use) and cattle (18 and $35 \%$ ) but cattle use ranged from 35 to $60 \%$ on the seeded sites.

Wildlife and cattle sequentially graze most range units in the Trench. Typically, cattle are grazed in spring or fall, while wildlife use the same ranges in early spring, fall and winter. Therefore, not all of the total standing crop is available to one ungulate species over the entire grazing season or during a specific foraging period. While cattle or wildlife may moderately use the forage available in a single grazing period, some range units are virtually continuously grazed even though range use plans prescribe rotational grazing for cattle. 


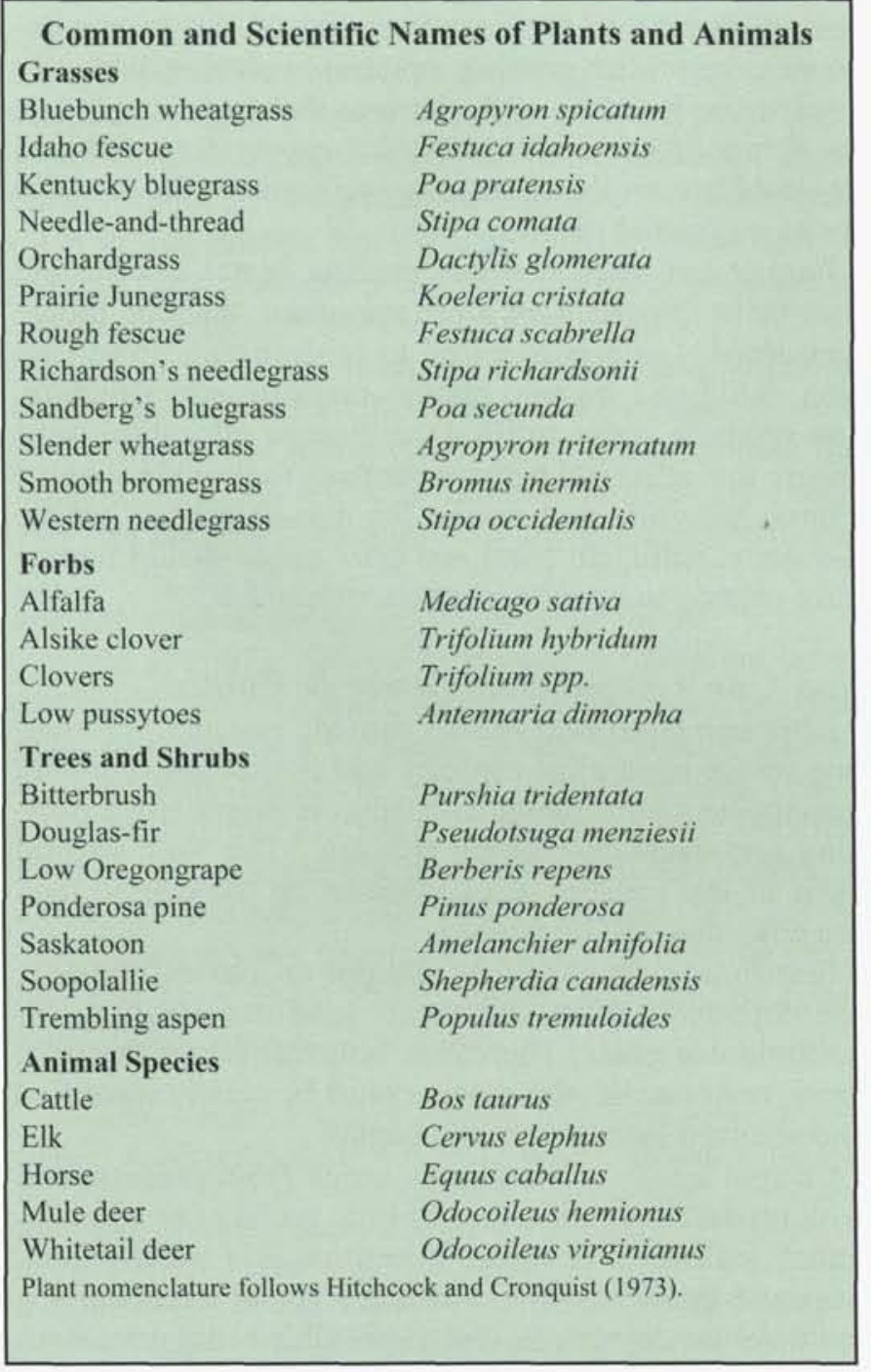

In addition to spring or fall cattle grazing, spring wildlife use ranged from 15 to $42 \%$ of the seasonal standing crop, from 14 to $50 \%$ in fall, and from 33 to $60 \%$ in winter among the four sites. Ultimately, range condition will decline if preferred species are repeatedly and heavily defoliated, and they are unable to store carbohydrates and set seed.

Spring cattle turnout dates should be based on plant growth stage and forage abundance, rather than on height measurements or calendar dates. In addition, cattle should not be turned-out on wildlife winter/spring ranges before forage plants have an opportunity to regrow after spring wildlife grazing. Not only will forage be limiting for cattle, but additional grazing may reduce the vigour of plants that were previously used.

Cattle rotations must provide adequate forage carryover for fall and winter wildlife demand. Although fall cattle grazing can reduce available forage for wildlife in fall and winter, pastures may receive more wildlife use in spring because forage plants contain less standing litter.
Cattle grazing is not the only factor affecting forage availability for wildlife on winter range. For example, deep snow limited herbaceous forage availability for deer and elk in winter 1993 at all sites except Premier Ridge. At Skookumchuck Prairie, browse increased to nearly $60 \%$ of elk diets in 1993 compared to about $20 \%$ in 1992 and 1994. Consequently, resource managers should not rely on herbaceous forage utilization entirely when estimating carrying capacity on common use ranges.

Multiple species grazing does not necessarily result in competition or deterioration of range condition. Facultative grazing, or using one herbivore to improve forage conditions for another species, can benefit both animal production and protect the range resource. For example, positive results have been achieved on mixed cattle, deer, and elk ranges in Oregon using $50 \%$ total forage use as the management goal.

\section{4) Plant Communities and Range Condition -} Results from monitoring, and personal observations, convince us that both cattle and wildlife are contributing to present conditions on Skookumchuck Prairie, Premier Ridge and Pickering Hills. All three sites are in early stages of succession and appear relatively static.

Several exclosures were constructed for this study but the duration of the project was too short to evaluate grazing effects. Very few reference areas exist in the East Kootenay where long-term data are available to compare grazed and ungrazed plant communities. An exception is the reference area exclosure at Skookumchuck Prairie that was constructed in 1951. This exclosure, and a grazed site adjacent to it, have been re-sampled at about 10 year intervals since 1960 .

Both the grazed and ungrazed sites were dominated by Sandberg's bluegrass, prairie Junegrass, needle-andthread and low pussytoes in 1951. Except for the replacement of Sandberg's bluegrass by needle-andthread, and minor fluctuations in forb cover, species composition in the grazed area has not changed significantly in 50 years. Clearly, combined use by deer, elk and cattle has maintained the grazed plant community in a low stage of succession.

Significant changes have occurred inside the exclosure over 50 years. With protection from ungulate grazing, bluebunch wheatgrass and rough fescue increased; and Sandberg's bluegrass, needle-and-thread, and low pussytoes all decreased from 1951 to 1970. Rough fescue and Idaho fescue have largely replaced bluebunch wheatgrass since 1970, but succession may not be complete, as Idaho fescue appears to be displacing rough fescue.

Furthermore, ponderosa pine established in the exclosure in 1982 and, by 1994, it had increased to nearly $13 \%$ cover. Fifty years of total exclusion from grazing and fire has resulted in the plant community progressing to a higher stage of succession typical of other ungrazed 
Ponderosa pine and Douglas-fir zones sites in the southern part of the province.

The plant communities at Premier Ridge and Pickering Hills will remain in a low successional stage if the present levels of heavy wildlife and livestock forage use continue. Both winter ranges are presently dominated by bitterbrush that successfully competes with bluebunch wheatgrass, rough fescue, and Idaho fescue.

Although bitterbrush can be valuable winter browse for mule deer in some years, it is generally used less by ungulates in the East Kootenay than elsewhere in the U.S. Consequently, a shift in the plant community to more perennial bunchgrasses will improve carrying capacity for combined use by cattle, elk and deer. In addition, forest encroachment is confining wildlife and livestock grazing to smaller areas at an escalating rate, and it is unlikely that grazing management alone will change species composition without other management inputs such as selective harvesting, juvenile spacing, and prescribed fire.

The conventional approach to range condition and trend using "climax" vegetation as the benchmark is not well suited to the East Kootenay because most of the valuable range for wildlife and cattle was derived from forestland. Moreover, higher stages of succession, with dense forest canopies, are not the most productive plant communities that optimize common use by wildlife and livestock.

The Society for Range Management Task Group on Unity and Concepts and Terminology (1989) recommended that multiple use objectives should be defined in terms of a Desired Plant Community (DPC). The DPC may not be the "climax" plant community, but it is the one best suited to meet the management objectives for the site.

We believe that the desired plant community approach is best suited for range management in large parts of the Trench, but objectives must be set on a site-specific basis and reflect attainable goals for the site. The present successional status of the community should be described and assessed with respect to the objectives of the plan.

If current species composition of the range needs to be altered, then options such as adjusting cattle stocking rates, fire, fertilizer, seeding, herbicides, or forest stand management can be explored.

\section{Biological Considerations In Forage Allocation}

Ostensibly, forage allocation is simply a process of dividing the forage on any management unit among herbivores. Often this process is applied to domestic livestock and wild ungulates but it could include any herbivores.

The biological foundation for forage allocation is carrying capacity, which links dietary preferences and for- age utilization to the sustainability of the forage resource. In mixed grazing systems, carrying capacity needs to be based on all herbivores that significantly use the forage. As a result, carrying capacity for combined ungulate use on the same range will not be the same as for an individual species.

Forage left after ungulate grazing is not wasted and may be as important, or more important, than the forage consumed. Litter is required to protect soils from erosion, build soil organic matter, maintain soil structure, and promote water infiltration. Forage allocation must ensure that adequate herbage remains to provide suitable habitat structure and forage for non-ungulate species. Similarly, sufficient plant and litter cover should remain after grazing to impede weed encroachment.

\section{You Can't Separate Science \& Politics}

Although biological factors provide essential information on the ecological capacity and limitations of a land management unit, forage allocation is essentially a planning and decision-making process. The fundamental basis of this process is a consensus on the overall land use ethic that will be pursued.

Conflicting agendas that attempt to maximize single use objectives often undermine land use planning for multiple-use goals. Therefore, political issues that will drive, or constrain, the process must be clearly identified and resolved before planning begins.

Current land use paradigms range from preservation with no use, to single use with little political or administrative influence. If forage allocation is a worthy goal, we must think broadly to balance social expectations, multiple-use objectives, and responsible ecosystem management. In other words - conservation with use.

This model acknowledges the importance of landbased products such as beef, wildlife, timber, water, and recreation while protecting soils and vegetation for longterm sustainability. Moreover, conservation values such as rare and endangered species, sensitive habitats, and archaeological sites, among others, can be identified and incorporated into the planning process.

In order for it to succeed, however, goals and objectives must be consistent with the ecological potential of the land management unit. Additionally, emphasis should focus on managing the landscape holistically with livestock and wildlife as components of the system.

In 1994, the East Kootenay Land Use Plan recommended "the government should direct the Ministry of Forests and the Ministry of Environment, as part of district and regional long-term planning requirements, to establish a strategic annual allowable livestock and wildlife grazing objective for Crown land based on the biological capacity of the resource, other user's interests and considering all potential forage sources." 
We concur with this recommendation and believe that forage allocation should be a principal component of range use planning in the East Kootenay on range units where there is common use by livestock and wild ungulates. Moreover, plans must be based on definable land units so that specific knowledge of diets, animal distribution, forage production and use, and other information can be incorporated into the planning process.

Some progress has been made in managing common use ranges in the East Kootenay. For example, grazing prescriptions are being modified to accommodate the needs of all forage users. In addition, projects are underway that address forest ingrowth and encroachment, and monitoring results from these projects will provide valuable information for management in the future.

While scientific data provide essential baseline information for planning and decision making, much depends upon personal interests, social values, economic considerations, inter-agency priorities, and government policy and legislation, as these all relate to equitability. Politics, at various levels, play an integral role in allocating forage in a responsible manner, but successful plans depends on sincere negotiation, decisions must be flexible, and plans should be evaluated regularly to determine if objectives are being met.

About the authors: Wikeem is a natural resource management consultant, Solterra Resources Inc., 4611 Westsyde Road, Kamloops, $B C, V 2 B 8 N 3$, Canada; and Ross is a certified range consultant, Ross Range and Reclamation Services, P.O. Box 283, Cranbrook, $B C, V I C 4 H 8$, Canada.

At the time of research, Wikeem was Range Scientist, Research Branch, BC Ministry of Forests, Kamloops, BC; and Ross was Range Ecologist, Research Branch, BC Ministry of Forests, Cranbrook, BC. This project was supported by the Sustainable Environment Fund, the Forest Resources Development Agreement, and the Kootenay/Boundary Grazing Enhancement Program.

\section{References}

Anderson, E.W. and R.J. Scherzinger. 1975. Improving quality of winter forage for elk by cattle grazing. J. Range Manage. 28:120125.

Ashford, R., E. Hobbs, A. Paulson, and J.E. Milroy. 1956. Grazing reconnaissance of the Cranbrook Stock Range. BC Ministry of Lands and Forests, Nelson Forest District, Nelson, B.C, $50 \mathrm{p}$.

Bircher, N., D. Janz, I. Hatter, and R. Forbes. 2001. East Kootenay elk management plan 2000-2004. BC Ministry of Environment, Lands and Parks, Wildlife Branch, 69p.

Choquette, W.T. 1971. Archaeological salvage operations within the Libby Dam pondage, 1971. Heritage Conservation Branch, Victoria, BC. Permit 1971-19. 13p.

Choquette, W.T. 1985. Archaeological salvage excavations at DjPv14, the Wild Horse River site, southeastern BC., Heritage
Conservation Branch, Victoria, B.C. Permit 1984-36. 228p.

Daubenmire, R.F. 1985. The western limits of the range of the American bison. Ecology: 66(2):622-624.

Demarchi, R.A., A.J. Woltersen-Strauss, and W.J. Warkentin. 1987. Managing elk by selective hunting in the east Kootenay subregion of British Columbia 1970 to 1986 . WAFWA/WDAFS Joint Conference. Salt Lake City, Utah, July 14, 1987.

Hall, F.C. 1989. The concept and application of growth basal area: a forestland stockability index.USDA Forest Service, Pacific Northwest Region R6 Ecol. Tech. Paper 007-88.

Hitchcock, C.L. and A. Cronquist. 1973. Flora of the Pacific Northwest. An illustrated manual. Univ. Wash. Press. Seattle. 730p.

Kelley, C.C. and P.N. Sprout. 1956. Soil survey of the upper Kootenay and Elk River Valleys in the East Kootenay District of British Columbia. Report No. 5 of the BC Soil Survey, Queen's Printer, Ottawa, Ont. 99p.

McLean, A. and E.W. Tisdale. 1972. Recovery rate of depleted range sites under protection from grazing. J. Range Manage. 25:178-181.

Owen, Stephen (Commissioner) 1994. East Kootenay land use plan. Commission of resource and environment. Victoria, B.C. $176 \mathrm{p}$.

Pitt, M.D. 1982. East Kootenay problem analysis. Interactions among grass, trees, elk and cattle. Research Branch, BC Minist. For., Victoria, B.C. 65 p.

Sugden, L.G. 1953. Range survey of the Elko deer sanctuary (1952). BC Game Comm. Special Rep., B.C Fish and Wildl., Victoria, B.C. $10 \mathrm{p}$
Statement of Ownership, Management, and Circulation

(Act. of August 12, 1970, Sec. 3685, Title 39, United States Code)

1. Title of Publication: Rangelands

2. Date of Filing: September 20, 2002

3. Frequency of Issue: Bimonthly

4. Location of Office of Publication: 445 Union Blvd., Ste 230, Lakewood, Colo. 80228

5. Location of General Business Office: Same

6. Name and Address of:

Publisher: Society for Range Management, 445 Union Blvd., Ste 230, Lakewood, Colo. 80228

Editor: Gary Frasier, 7820 Stag Hollow Rd, Loveland, Colo. 80538

Managing Editor: Kindra Gordon, P.O. Box 645, Spearfish, South Dakota 57783

7. Owner: Society for Range Management, 445 Union Blvd., Ste 230, Lakewood, Colo. 80228

8. Known Bondholders, Mortgages, etc.: Membership

9. For Completion by Nonprofit Organizations Authorized to Mail at Special Rates: The purpose, function, and nonprofit status of this organization and the exempt status for Federal income tax purposes have not changed during preceding 12 months.

10. Extent and Nature of Circulation

\begin{tabular}{lcc|} 
Avg. for & $\begin{array}{c}\text { Actual for } \\
\text { issue nearest } \\
\text { filing date }\end{array}$ \\
A. Total copies printed & 12 months & 3,614 \\
B. Paid Circulation & 3,703 & 0 \\
1. Dealers, counter sales & 0 & 3,359 \\
2. Mail subscriptions & 3,445 & 3,510 \\
C. Total paid circulation & 3,597 & 11 \\
D. Free distribution & 11 & 3370 \\
E. Total distribution & 3,456 & 247 \\
F. Copies not distributed & 247 & 3,614 \\
G. Total & 3,703 & \\
I certify that the statements made by me above are correct and complete -Samuel \\
Albrecht, Executive Vice President. & & \\
& & \\
\end{tabular}

